\title{
Karykatura - groteska - ironia - humor w literaturze czasów saskich Jan Stanisław Jabłonowski i Karol Mikołaj Juniewicz
}

Sławomir Baczewski 
nAPTS Seria XIV 2008

\section{Sławomir Baczewski}

\section{Karykatura - groteska - ironia - humor w literaturze czasów saskich: Jan Stanisław Jabłonowski i Karol Mikołaj Juniewicz}

\section{Dwa nurty satyry obyczajowej}

$\mathrm{P}$ oniższy szkic nie ma pretensji do wyczerpania tematu choćby w części; jego celem jest przedstawienie zagadnienia satyry i ironii w twórczości dwóch pisarzy czasów saskich — Karola Mikołaja Juniewicza (1697-1756) i Jana Stanisława Jabłonowskiego (1669-1731)'. Lokują się oni na dwóch biegunach piśmiennictwa tamtej epoki. Juniewicz kojarzony jest z literaturą niską, popularną, Jabłonowskiemu natomiast bliżej było bez wątpienia do oświeconego sarmatyzmu i do prekursorów oświecenia ${ }^{2}$. I u Jabłonowskiego, i u Juniewicza jednak wątki satyryczne powiązane są z dewocją i nakładają się na nią, a ironia służy ostremu osądowi zjawisk społeczno-politycznych. W spuściźnie po nich pozostały teksty, które w zamierzeniu przynajmniej — miały dać krytyczną diagnozę ich współczesności.

Juniewicz jest spadkobiercą potrydenckiej pedagogiki strachu i satyry XVII wieku, Jabłonowski natomiast oscyluje między tradycją literacką baroku a pierwszymi jaskół-

Do dnia dzisiejszego podstawową i najdokładniejszą pracą na temat satyry w czasach saskich jest studium Pauliny Buchwald-Pelcowej Satyra czasów saskich (Wrocław 1961).

2 Pojęcie to odnosi się raczej do historii sztuki, ale można je zużytkować na potrzeby wydzielenia pewnej części elity społecznej XVII i pierwszej połowy XVIII wieku - por. M. Karpowicz, Sztuka oświeconego sarmatyzmu. Antykizacja i klasycyzacja $w$ środowisku warszauskim czasów Jana III, Warszawa 1986. W poczet prekursorów nowego myślenia (pod względem politycznym) zaliczył Jabłonowskiego Władysław Konopczyński — zob. idem, Polscy pisarze polityczni XVIII w. (do Sejmu Czteroletniego), Warszawa 1966, s. 61 i nast. Tak też postrzega go Mieczysław Klimowicz (Oświecenie, Warszawa 2002, s. 64), jak i Czesław Hernas, który jednak widzi u niego raczej „sarmatyzację” klasycyzmu (zob. idem, Barok, Warszawa 1999, s. 539-543). 
kami klasycyzmu ${ }^{3}$. Z tego względu stylistycznie bliższy wydaje się mu Antoni Poniński i jego Sarmatydy, $z$ ich filozoficznym zacięciem oraz skłonnością do poszukiwania moralistycznych uogólnień i głębszych źródeł nadużý obyczajowych ${ }^{4}$. Na tym jednak bezpośrednie podobieństwa się kończą. O ile zapleczem ideowym dla satyry Ponińskiego jest filozofia stoicka, to u Jabłonowskiego funkcję tę spełnia etyka ugruntowana na religii w jej ortodoksyjnie katolickim wcieleniu ${ }^{5}$. Wspólnotę jednak wyznacza dyskursywny charakter Skruputu bez skrupułu oraz Sarmatyd, jak też niewątpliwa zbieżność kultury umysłowej ${ }^{6}$. Sarmatyd $y$ mają ponadto pewne związki także z anonimową satyrą Matpa-czlowiek $w$ cnocie, obyczajach $i$ kroju, niekiedy przypisywaną Ponińskiemu i wykazującą ideowe zbieżności z moralistyką Sarmatyd?. O Matpie-człowieku należy wspomnieć tu choćby okazjonalnie, bo jest to chyba najciekawsza satyra pierwszej połowy XVIII wieku. Sarmatydy i Matpa-cztowiek to swego rodzaju etapy pośrednie, wiodące od Skruputu... Jablonowskiego ku Refleksyjom duchownym Juniewicza, których redakcja z roku 1753 w syntetycznych ambicjach bliska jest anonimowej satyrze przypisywanej Ponińskiemu.

\section{Jan Stanisław Jabłonowski}

Jeśli chodzi o satyrę, to w odniesieniu do Jabłonowskiego najczęściej przywołuje się opublikowany u schyłku życia autora Skrupuł bez skruputu, który sytuuje się na pograniczu satyry obyczajowej i politycznej, aczkolwiek ta pierwsza w Skrupule... odarta jest $z$ drapieżności, raczej realizując się $\mathrm{w}$ stonowanym dydaktyzmie. I chociaż liczne pozostałe po Jabłonowskim pamiętniki potwierdzają, że wrodzona złośliwość nie leżała w jego naturze, to jej miejsce zajmuje gorycz, obecna w licznych uwagach za-

${ }^{3}$ Jabłonowski przetłumaczył część bajek w Ezopie nou'ym z La Fontaine'a, ale ubiera je w szatę tradycyjną (bliską Setnikowi opouvieści uciesznych Marcina Blażewskiego, kontynuującego tradycję bajki renesansowej łacińskiej), a przekładając Telemacha, nadaje mu charakter tradycyjnej barokowej epopei, rezygnując z formy prozatorskiej na rzecz epiki wierszowanej.

${ }^{4}$ Zob. M. Skrzypek, Wstęp w: A. Poniński, Sarmatides seu Satyrae, tł. A. Mączyńska-Dilis, opr. M. Skrzypek, Kraków 2005, s. 23 i nast.

${ }_{5}$ Tak jest w Skrupule bez skrupułu; ogólne omówienie tego tekstu zob. W. Konopczyński, Polscy pisarze polityczni XVIII $w \ldots . .$. , op. cit. Pierwodruk Skrupułu... ukazał się w roku 1730 we Lwowie, anonimowo. ${ }^{6}$ Nie zmienia to faktu, że związki Ponińskiego ze staropolską tradycją gatunku są czysto zewnętrzne. Bierze on z niej głównie pomieszanie postaci Satyra i gatunku satyry, które ujednolica — choć współcześnie wydaje się to naiwne - umieszczając swe Sarmatki w literackim królestwie satyrów, reprezentującym dobrotliwy stan natury; jest w tej mierze spadkobiercą tradycji poematu satyrowego. W jego obrębie przywilej czystości obyczajów należal satyrom z natury jako ostatnim reprezentantom złotego wieku; gdzież zatem, jak nie pośród nich, miałby Poniński szukać doskonałości?

${ }^{7}$ Zob. M. Skrzypek, op. cit., s. 38. Tekst Małpy wydała Paulina Buchwald-Pelcowa („Archiwum Literackie", t. 6: Miscellanea staropolskie, t. 1, Wrocław 1961, s. 154-331), jak też poświęciła jej sporo miejsca w swojej monografii (Satyra czasów saskich, op. cit.). 
wartych w Skrupule..., dotyczących na przykład skłócenia wszystkich ze wszystkimi w Rzeczypospolitej ${ }^{8}$, a gryząca ironia stanowi jeden z podstawowych środków wyrazu dla autora. Miała ona może źródła w fakcie, iż Jabłonowski swoje polityczne sympatie zwykle lokowal po niewłaściwej stronie, co mogło zaowocować zgorzknieniem. Dwukrotnie nietrafnie obstawial kandydaturę do tronu, w 1697 i 1706 roku, pozostając ciągle wiernym szeroko pojętej fakcji profrancuskiej ${ }^{9}$. Niejednokrotnie pozostawało mu więc tylko szyderstwo, takie jak wówczas, gdy w Skrupule... pisze o manifeście Augusta Mocnego, w którym władca szeroko wyjaśniał powody swego powrotu na tron. Jabłonowski skwitował to jednym zdaniem, iż winien był napisać: „że króla szwedzkiego na głowę pobito i do Turek wygnano, tedy dla tej racyi powracam do Polski”"

Tak jak szydził z Sasa, tak też nie żałował kąśliwych uwag swoim współczesnym, piętnując między innymi pozorną równośc, warcholstwo i prywatę. Atak na etyczną degrengoladę był w duzej mierze osobistym rozrachunkiem z przeciwnikami, a nie zobiektywizowanym osądem, bo wytykając współczesnym niedostatki moralne i zwykłe błędy, Jabłonowski najwięcej uwagi poświęcał sprawom, w które zaangażowany był on sam i jego rodzina, takim jak ocena domu Sobieskich czy kwestia elekcji po śmierci Jana III. Tę obronną i nieco paszkwilancką nutę widać choćby w anegdocie o motywacjach przeciwników Sobieskiego: „niech król Jan zostanie żydem, to on chrześcijaninem, et e contra i vice versa" ${ }^{11}$.

Tym, co szczególnie poruszało Jabłonowskiego w kreślonym w Skrupule... obrazie społeczności szlacheckiej i jej stosunku do władzy, była obserwacja, iz zasadę stanowiła nie tyle nawet walka o interesy, co zwykla złośliwość, „dokuczanie” - by użyć tu kolokwializmu, który najlepiej oddaje zjawisko, zwane przez Jabłonowskiego „weksowaniem”. Jeżeli król powiadał "tak” — sugeruje Jabłonowski — koniecznie trzeba było odrzec mu: „nie”'12. W niekoniecznie krzywym zwierciadle odzwierciedlił wojewoda ruski sposoby, którymi owo „nie” lagodzono, przytaczając anegdotę o Rafale Leszczyńskim, ojcu niefortunnego króla Stanisława, skądinąd siostrzeńca Jabłonowskiego. Miał on rzec: „A który to tam taki syn, któremu nie dałem?”. Gorzkie szyderstwa, podob-

${ }^{8}$ Zob. J. S. Jabłonowski, Skrupuł bez skrupułu albo oświecenie grzechów narodowi naszemu polskiemu zuyczajniejszych, a za grzechy nie mianych. Traktat po prostu grzech roztrzasajacy, na rozdziały podzielony, przez pewnego Polaka tymiż grzechami grzesznego ale żałujacego, na poprawe swoje i hudzka podany, wyd. K. J. Turowski, Kraków 1858, s. 8.

9 Było to uwarunkowane rodzinnymi koligacjami Jabłonowskiego. Był żonaty z siostrzenicą Marysieńki Sobieskiej, Joanną de Béthune, a jego siostra Anna była matką Stanisława Leszczyńskiego zob. J. Gierowski, Jan Stanistaw Jabłonowski, hasło w: Polski słownik biograficzny, t. 10, Wrocław 1964, s. 221-222.

${ }^{10}$ J. S. Jabłonowski, Skruput..., op. cit., s. 11.

${ }_{11}^{1}$ Ibidem, s. 19.

12 Tę potrzebę mówienia „nie” warto by było zestawić z ideą szlacheckiej wolności, w której prawo do oporu miało charakter podstawowego przywileju. 
ne do powyższych, stały się w Skrupule... rodzajem ideologii. Przezierają one przez szkic patologii funkcjonowania aparatu państwowego Rzeczypospolitej, zilustrowany przykładem urzędu podskarbiowskiego. Według Jabłonowskiego, większości narodu politycznego chodziło o to, aby się na sprawowanym urzędzie obłowić, a potem go porzucić beztrosko. Tak samo jak urzędy, wedle Skruputu... funkcjonowały sejmiki, gdzie także najgłośniej przemawiało złoto. Podskarbiostwo, sejmiki zwykłe i gospodarcze stanowily pod piętnującym piórem autora Skruputu... swego rodzaju pars pro toto dla opisu sejmu. Tragiczny w gruncie rzeczy obraz dopelniony został przez sądownictwo, trybunały koronne, które, jak pisze Jabłonowski: „słuszniej morzem nazwać mogę zdrad, oszukań, do przedłużania spraw, do zastraszenia i do samego przegrania niesprawiedliwego inwencyi" ${ }^{13}$. Jabłonowski skreślił szkic państwa na wskroś przeżartego przez korupcję, w którym rolę wędzidła wolności spełnia nie opresyjny monarcha absolutny, ale o ileż bardziej wszechmocne pieniądze. O sobie samym w tym kontekście autoironicznie napisal, iż także mógł się nieco obłowić, ale nie uczynił tego, ponieważ dba o swoje sumienie. W związku z tym jedyną dla niego drogą nieprzyczyniania się do powszechnej degrengolady było zamknięcie się w sprawach prywatnych, co też, jak pisze $z$ satysfakcją, uczynił. Tak więc szyderstwa Jabłonowskiego formułowane były $z$ wygodnej perspektywy wzniosłego nieuczestniczenia.

Obraz codzienności społeczno-politycznej uzupełnił Jabłonowski w Skrupule... wizją „grzeszków prywatnych", piętnując przede wszystkim spryt i zapobiegliwość kobiet, które z pożytkiem dla siebie, a jego zdaniem niesłusznie, korzystały z fortun pozostawionych przez zmarlych męźów; zwie je „bezecnymi wdowami”"14. Nawiasem mówiąc, poświadczyl tu wojewoda ruski ustalenia badaczy, że pośród stanów cywilnych wdowieństwo dla kobiet było w epoce staropolskiej najkorzystniejsze ${ }^{15}$. Dalsza część Skruputu... byla przede wszystkim obroną ekonomicznych interesów autora, stanowiąc dość trywialny atak na dzierżawców szlacheckich oraz żydowskich arendarzy, ponoć bez żenady wykorzystujących dziedzicznych właścicieli; tutaj także podstawową formą wyrazu była gorzka ironia, pomieszana $z$ tendencją do racjonalizacji wlasnych twierdzeńn ${ }^{16}$.

Poprzez rozważający, a nie tylko opisujący dyskurs, Jabłonowski zerwał w nim z wypracowaną wcześniej, siedemnastowieczną tradycją satyry ${ }^{17}$, pozostając odległym również

\footnotetext{
${ }^{13}$ Ibidem, s. 33.

${ }^{14}$ Ibidem, s. 39.

${ }_{15}$ Zob. M. Bogucka, Białogłowa $w$ daunej Rzeczypospolitej, Warszawa 1998, s. 59.

${ }^{16}$ Zob. J. S. Jabłonowski, Skruput.., op. cit., s. 42-43.

${ }_{17}$ Jabłonowski nie nawiązuje ani do konwencji satyr o korzeniach rzymskich, ani też do tradycji poematu satyrowego; szerzej o tradycji zob. S. Grzeszczuk, O „Satyrach” Krzysztofa Opalińskiego. Próba syntezy, Wrocław 1961; J. Nowak-Dłuzewski, Poemat satyrouy w literaturze polskiej XVI-XVII wieku. $Z$ dziejów inicjatyny artystycznej Jana Kochanowskiego, Warszawa 1961, jak też P. Buchwald-Pelcowa, Satyra czasów saskich, op. cit., zwl. s. 10-51.
} 
od stylistyki Matpy-człowieka. To właśnie quasi-analityczne podejście zbliżyło go do Anatomii Rzeczypospolitej Stefana Garczyńskiego czy Listu ziemianina Stanisława Poniatowskiego.

Nie potrafił jednak wojewoda ruski zdecydować się na wierność jakiejś jednolitej formule. Nawet w przerażającym obrazie sejmików szlacheckich, Trybunału i sejmów mimo wszystko starał się zachować powściągliwość, a jego wywód miał charakter względnie umiarkowany, skoro autor nie dał się ponieść naturalnej w tej sytuacji tendencji do skrajnego przerysowania, które znajdziemy choćby u Juniewicza. Pisarz pragnąl dotrzeć do źródeł zepsucia, nie byl jednak w ostatecznym rozrachunku radykalem, ponieważ nawoływał do powrotu do „staropolskiej cnoty”, ale przede wszystkim widział możliwość korekty tego, co złe, w aplikowaniu do życia codziennego nakazów moralnych, płynących z etyki chrześcijańskiej. W związku z tym praktycznych wskazówek sposobu naprawy państwa w Skrupule... zabrakło, co naturalne z tej perspektywy.

W quasi-racjonalizującym podejściu nie był Jabłonowski odosobniony. Antoni Poniński, z którym pewną wspólnotę autora Skruputu... już tu odnotowano, w toku dyskursu przypomina Jabłonowskiego, który starał się dać rodzaj religijno-politycznosatyrycznego obrazu bolączek życia codziennego. Poniński natomiast w swoich niedokończonych Sarmatydach połączył w jedno poemat filozoficzny, czy wlaściwie rodzaj traktatu o obyczajach i obyczajowości, z elementami autentycznej satyry; tak jak u Jabłonowskiego niejednokrotnie wydobywa się ona z trudem $z$ dydaktycznego dyskursu filozoficznego. Ambiwalencja jest większa u Ponińskiego, ponieważ zdaje się on znać tradycję poematu satyrowego i podążać w trop za swoistym pomieszaniem genologicznym, które utrwalil jeszcze Twardowski, czyniąc patronami swego Satyra na twarz Rzeczypospolitej Persjusza i Juwenalisa, ale zarazem nawiązując do Lukrecjusza ${ }^{18}$.

W twórczości Jana Stanisława Jabłonowskiego na Skrupule... obecność wątków satyrycznych czy raczej szerzej: komizmu się nie wyczerpuje. Znajduje on dla siebie sporo miejsca w Ezopie nowym polskim. Zbiór ten składa się z dwóch części - Żywota Ezopa Fryga oraz antologii zatytułowanej Sto i oko bajek ${ }^{19}$. Do dnia dzisiejszego nie doczekał się on nowoczesnej edycji, aczkolwiek sądzę, że niewątpliwie na nią zasługuje, jako utwór zdecydowanie wybijający się na tle produkcji wydawniczej pierwszej połowy XVIII wieku.

\footnotetext{
${ }^{18} \mathrm{~W}$ dwóch punktach pozostał Poniński tradycji staropolskiej wierny — w mizoginizmie i krytycznym osądzie Trybunału; osobliwością jest u niego jednak, połączone w jedno, krytyczne widzenie patologii sądownictwa najwyższego szczebla jako efektu zakulisowych działań „alkowianych”. Nowością całkowitą było pojawienie się tematu pojedynków, który potem zaistnial w Punkcie honoru Dembowskiego, pierwszej prawdziwie nowoczesnej satyrze czasów saskich - zob. A. S. Dembowski, Punkt honoru, w: Poeci polskiego baroku, wyd. J. Sokołowska, K. Żukowska, t. 2, Warszawa 1965, s. 475-484.

${ }_{19}$ J. S. Jabłonowski, Ezop nowy polski, to jest życie Ezopa filozofa frygskiego. Sto i oko bajek przy tym uybranych $z$ ksiag różnych autorów niektórych teė Ezopa niektórych autora inwencyi i wierszem polskim z krótka przy każdym moralizacyja spisane, Lipsk 1731. Dalsza lokalizacja przytoczeń i odwołań — bezpośrednio w tekście.
} 
Załączony do Ezopa nowego polskiego żywot greckiego bajkopisarza zaprzecza przekonaniu, że na przestrzeni XVII wieku dzieło Biernata $\mathrm{z}$ Lublina wyszło $\mathrm{z}$ obiegu czytelniczego. Wedle wstępnych deklaracji samego Jabłonowskiego, punktem wyjścia dla jego zbioru miał być La Fontaine i jego Fables ${ }^{20}$. W praktyce jednak La Fontaine pozostał wzorcem deklaratywnym. Choć zbiór jego bajek zawierał rzeczywiście żywot Ezopa, to polski autor z początków XVIII wieku skorzystał z niego w sposób specyficzny: parafrazując tekst La Fontaine'a, i nie oparł się pokusie skorzystania $z$ istniejącego Ezopa Biernatowego, wobec którego przeróbka Jabłonowskiego wykazuje bezpośrednie tekstowe filiacje. Liczne bezpośrednie nawiązania realizują się w sparafrazowanych cytatach z Żywota Biernatowego. Zależność uwidocznia się nawet $\mathrm{w}$ formie: La Fontaine'owski żywot spisany był prozą; Jabłonowski w ślad za wzorem Biernata utrzymał wiersz. Podobnie rzecz ma się ze zbiorem bajek. Ich formuła: „sto i oko”, czyli sto jeden bajek pochodzi z tradycji schyłkowego renesansu, a nie francuskiego klasycyzmu, i na gruncie polskim najbliższy mu jest Setnik przypowieści uciesznych Marcina Blażewskiego ${ }^{21}$.

U Biernata ogromną rolę spełniała krytyczna obserwacja stosunków społecznych $\mathrm{i}$ ich osąd $\mathrm{z}$ perspektywy czlowieka zdeklasowanego, niemającego swojego miejsca w hierarchii. Jabłonowski jako reprezentant elity społecznej czasów Augusta II (choć był u króla w niełasce) nie mógł do końca przyjąć za swoją drapieżnej wizji stosunków spolecznych, która w Żywocie Ezopa Fryga była bezpośrednim źródlem komizmu²2. $\mathrm{Z}$ postaci nieustraszonego bojownika o wolność, jaką wykreował antyklerykalny Biernat, pozostał w Ezopie nowym polskim błazen i mędrzec, niekonstestujący ladu społecznego. Z prześmiewczej kreacji, wyszydzającej autorytety moralne i porządek świata, utrzymany został tylko wątek antyfeministyczny, a konflikt między Ezopem a żoną Ksanta urósł omalże do rangi dramaturgicznego centrum utworu, stanowiąc jeden z wielu elementów antyfeministycznej satyry, ostrzejszej u Jabłonowskiego niż w utworze Biernata. Drastyczna wizja rzeczywistości, porządkowanej przez prawo pięści, została ucywilizowana i złagodzona, ponieważ Jabłonowski przefiltrował swoją narrację o Ezopie przez pryzmat doświadczenia francuskiego klasycyzmu, usuwając między innymi liczne fizjologizmy i większość niewybrednych żartów, odnoszących się do biologicznych aspektów ludzkiej egzystencji. Pozostawil tylko konieczną początkową scenę, w której poprzez wywolanie wymiotów Ezop dowiódł swojej niewinności. Najprawdopodobniej poeta uznał za niedopuszczalne, aby „prostackie”

\footnotetext{
20 Zob. Przedmowa, w: ibidem, k. A3 $v$.

${ }_{21}$ Szerzej na ten temat: J. Abramowska, Polska bajka ezopowa, Poznań 1991. Abramowska podkreśla lafontenizm Jabłonowskiego.

22 Por. liczne prace na ten temat Stanisława Grzeszczuka: Błazeńskie zwierciadło. Rzecz o humorystyce sowizdrzalskiej XVI i XVII wieku, Kraków 1994, Staropolskie potomstwo Sowizdrzała, Warszawa 1990 oraz przede wszystkim Wstęp w: Biernat z Lublina, Ezop, Kraków 1997.
} 
koncepty, na których bazował sowizdrzalski z ducha dowcip Biernatowy, mogły znaleźć się w dziele, które za wzór swój (niezgodnie z realizacją faktyczną) podawało La Fontaine'a.

Bajka Jabłonowskiego nie jest „czystym” apologiem, ale niejednokrotnie sytuuje się na pograniczu facecji, satyry, a nawet baśni - bo i takie teksty w zbiorze Sto i oko bajek odnajdziemy (np. bajki 10 Smok, lis i chtop i 46 Król i pastuch). „Bajka” w jego ujęciu była gatunkiem na tyle pojemnym, że w zbiorze pomieścily się wierszowane nowele (Efeska matrona czy Białogłowa i sekret), jak też teksty kontynuujące tradycję fraszki staropolskiej (Baba w nowym kożuchu).

$\mathrm{Z}$ treści satyrycznych najsilniej obecne są w zbiorze wątki antyfeministyczne. Wyrażają je teksty takie jak między innymi Białogłowa i sekret, Żona i diabet oraz wspomniana już Efeska matrona. Ta ostatnia jest przetworzeniem popularnego tematu, mającego swoje źródła w Satyrykach Petroniusza, opowiadającego o kobiecie omdlewającej z bólu po stracie męża, rychło jednak znajdującej pociechę u boku spotkanego nad mężowskim grobem kochanka ${ }^{23}$.

Jak wspomniałem, termin „bajka” jest dla Jabłonowskiego tak pojemny, że włącza on do swego zbioru także obiegowe anegdoty, takie jak ta o tyranie Syrakuz Polikratesie, któremu pewna kobieta życzyła długiego życia, tłumacząc mu:

„[...] znalam ja i ojca twego,

Ten był dosyć zły, i ludzie go klęli

Poty, aż z świata bogowie go wzięli.

Wysłuchali ich, biorąc nam dość złego,

Ale ci w zamian dali nam gorszego,

A to jest ciebie. To zaś ja gdy widzę,

Żeby nad ciebie gorszy, w naszej bidzie,

$\mathrm{Na}$ tron po tobie nie nastąpil panem,

Modlę się bogom, padając kolanem,

Żebyś ty już żył, i panował z lichem" -

Tak przymawiała ta baba z uśmiéchem [51. Tyran i baba, s. 122].

Polityczna satyra w zbiorze bajek pojawia się tylko dwa razy: w bajce 69 , nawiązując do fakcyjnych podziałów w Rzeczypospolitej, oraz szeroko w bajce 97 Lucyper po świecie lecacy, tak tłumaczącej źródła ciągłych kłótni w Polsce: oto spadając z nieba,

23 Ta sama zresztą historia została przytoczona niedługo potem w Sarmatides Ponińskiego, zaczerpnięta albo z popularnego wówczas Ezopa nourego polskiego, albo bezpośrednio z Petroniusza, którego imiennika uczynił Poniński jednym z bohaterów swojej anegdoty o niestałości kobiet - zob. A. Poniński, Sarmatides seu satyrae..., op. cit., s. 223-321; J. S. Jabłonowski, Ezop nouү..., op. cit., s. 209-214; Petroniusz, Satyryki, tl. i opr. M. Brożek, Wrocław 1968 (BN II 154), s. 135-139. 
Lucyfer rozpadł się na kawałki, różne części jego ciała spadły na różne narody, dając początek narodowym grzechom. Na Polskę spadły tylko tablica do spisywania grzechów, kreda i gąbka:
Że zaś Lucyper miał tablicę, lichy
$Z$ kretką i gąbką, do pisania grzéchy,
Te troje $z$ ręku diabelskich wypadly,
I na Królestwo nasze Polskie padły.
Stąd my Polacy, kiedy się zjedziemy
$\mathrm{Na}$ komisyją, wszystko rachujemy,
A pieniędzy nic wojsku nie dajemy.
Gdy zaś na sejmy walne się zjeżdżamy,
Jedne mażemy, drugie poprawiamy,
Trzecie na nowo prawa piękne piszem,
O egzekucji jak żywo, nie słyszem,
Stąd też widziemy, co się z Polską dzieje,
Polak ją płacze, cudzoziemiec śmieje [s. 221].

Nie brak też $\mathrm{w}$ bajkach ironii, pomieszanej z satyrą obyczajową, pojawiającą się od niechcenia, tak jak miało to miejsce w bajce pierwszej: Szczur i ser holenderski (s. 1), gdzie szczur udał się na pokutę do spiżarni, za pustelnię obierając sobie krążek sera, a w finale bajki odgania inne szczury, bo chce umartwiać się samotnie w swym eremie; całość jest satyrą na hipokryzję fałszywych bigotów. Podobnie jest w bajce 38 Btazen, co rejestr błaznów pisat (s. 91), będącej kpiną z naiwności. Błazen wpisuje tam do rejestru błaznów swego pana, bo ten dal pieniądze pewnemu węgierskiemu kupcowi, aby węgrzyna mu przywiózł, a nie wziął żadnego pokwitowania. Puentą jest, jak pisze Jabłonowski, polskie mądre przysłowie: nie wierz nikomu, a nikt cię nie oszuka. Podobnie prześmiewcza jest autorska bajka Jurysta i diabeł (s. 240), gdzie główny bohater — prawnik - bezskutecznie starał się nie trafić do piekła.

Chociaż nie brak u Jabłonowskiego odniesień do wspólczesności, to jednak w dużej mierze humorystyczne i ironiczne akcenty obecne w Stu i oku bajek są dziedzictwem tradycji bajki ezopowej.

\section{Karol Mikołaj Juniewicz}

Karol Mikołaj Juniewicz nie ustępował bynajmniej wykształceniem czy to Jabłonowskiemu, czy Ponińskiemu, jego twórczość jednak znalazła się na drugim biegunie literatury saskiej. Wywodził się on z niezamożnej szlachty, a całe dojrzałe życie spędził w klasztorze, co odcisnęło się na jego twórczości. Ten paulin częstochowski w swoich Refleksyjach duchownych na mądry Salomona sentyment łączył sprzeczności, będąc erudytą w masce ludowości. Wrażenie tej ostatniej uzyskał dzięki dosadności wyrażania się 
i śmiałości środków ekspresji. Juniewicz posługiwal się pełną paletą chwytów satyry, wypracowanych w staropolskiej tradycji, a ze względu na rzekome gębokie inspiracje biblijną Księgą Eklezjastesa umieścił w roli mędrca — zamiast postaci Satyra - króla Salomona. Juniewicz wyzyskał nie tylko konwencjonalny zasób tematów, znanych już z Satyr Opalińskiego (i tekstów wcześniejszych, od Krótkiej rozprawy Reja i Satyra Kochanowskiego począ̧szy), ale też rozpowszechnioną w wieku XVIII konwencję „lamentów Korony”. Osobliwością Refleksyj duchownych jest język i sposób wyrażania poglądów, lokujący się na pograniczu stylu niskiego i literatury plebejskiej, zarazem jednak niewolny od erudycyjnych popisów.

Poemat Juniewicza zachowal się w dwóch wersjach: starszej (1731), bliższej czasowo Skruputowi bez skruputu, i młodszej (1753), sąsiadującej raczej z Punktem honoru i Sarmatydami. W starszej wersji poematu żywioł satyryczny był nieco mniej eksponowany. W drugiej, dwukrotnie obszerniejszej redakcji ma on już miejsce dominujące, spychając na margines nie tylko „refleksje polityczne”, ale też zagadnienia religijne ${ }^{24}$.

Do pierwszorzędnych sposobów wyrazu zalicza się w Refleksyjach duchownych karykatura. Jak daleko ona sięga, niech zaświadczy przedziwna teoria na temat upadku Rzy$\mathrm{mu}^{25}$, zgodnie z którą nastąpil on w efekcie niepohamowanego obżarstwa, czy swoista wariacja na temat frazy Kochanowskiego: „Pańska ręka mnie dotknęla”, otwierającej Tren XVII, brzmiąca u Juniewicza:

\author{
Tknie cię Bóg palcem \\ A wnet padalcem \\ Po skokach leżysz [1731, s. 81; 1753, s. 120] —
}

lub też inna, przetwarzająca melancholijny topos Ubi sunt — gdzie Midas

\author{
złotem obżarty $[\ldots]$ \\ Utonął w smole, \\ Acz w złocie pływal.
}

\footnotetext{
${ }^{24}$ Dwa główne wydania to: K. M. Juniewicz, Refleksyje duchowne na mądry króla Salomona sentyment oraz na krótkość życia ludzkiego, śmierć, sąd straszny, wieczność szczęśliwą i nieszczęśliwa, krótkim polskiego rytmu stylem chrześcijańskiemu oku spod umbry zakonnej na widok wydane..., Częstochowa 1731; idem, Refleksyje duchowne na mądre o próżności śutiatowej króla Salomona zdanie oraz na krótkość życia ludzkiego i uszystkich rzeczy przemijajacych, śmierć, sqd straszny, wieczność szczęsliwa i nieszczęsliwa; z przydatkiem żalu i lamentów grzesznika bioracego w' rozsq̨dna uw'age też same w' wyrażonych punktach refleksyje; twdzież okrutna mękę Paniskq, krótkim polskiego rytmu nowo inwentowanego stylem, Wilno 1753 (w tymże roku ukazało się też wydanie pod zmienionym tytułem: Uwagi pobożne i polityczne na mądre króla Salomona o próźności światowej zdanie... krótkim nowej invencyi wierszem polskim remostrowane a wielkiemu imieniowi i honorowi Jaśnie Wielmożnego Jego Mości Pana Platera starosty giegobrockiego dedykowane). Ze względu na daleko posunięte różnice między wersjami tekstu, w dalszych przytoczeniach (lokalizowanych bezpośrednio w tekście głównym) będę oznaczać datę wydania każdej z redakcji.

${ }^{25}$ Zob. K. M. Juniewicz, Refleksyje..., 1753, s. 99.
} 
Także śmierć pod piórem Juniewicza jest śmiesznie trywialna:

$$
\begin{aligned}
& \quad[\ldots] \text { Rzucać się będziesz } \\
& \text { W okropnej trwodze. } \\
& {[\ldots]} \\
& \text { Szpetnie zbledniejesz, } \\
& \text { Pianą się zlejesz, } \\
& \text { Przejmą cię zmory [...] }
\end{aligned}
$$

Nic nie zostanie,

Tylko jękanie [1731, s. 88; 1753, s. 134].

Posługując się chętnie karykaturą, bliską nieraz grotesce, Juniewiczowska satyra obyczajowa dotykała tematów, takich jak antyfeminizm, który łączy Refleksyje duchowne z twórczością Jabłonowskiego, Sarmatydami, anonimową Matpq-człowiekiem oraz tradycją wcześniejszych stuleci. Kobiety u Juniewicza są pyszne i leniwe ${ }^{26}$. Wiele wysiłku wkładają w uchylanie się od pracy, a drobiazgi tak bardzo je rozpraszają, że nie mają czasu na ugotowanie obiadu ${ }^{27}$. Rozrzutność jest dla nich naturalna, ale bardziej zatrważająca okazuje się słabość do trunków i przewrotność, wyrażająca się choćby w zdradzie na oczach męża. Jedyną rzeczą rzeczywiście kobiety interesującą jest

Lice wygładzić

Twarzy pieszczonej,

Trefić, pudrować,

Włosy farbować [1731, s. 50; 1753, s. 79; 1753 (2), s. 65].

Aby zaradzić całemu złu, którego powodem są kobiety, poeta udziela rad tradycyjnych, zalecając bicie ${ }^{28}$.

Ale karykaturalny obraz kobiet był tylko częścią większego zamierzenia, obejmującego wszystkie stany, w tym szlachtę płci męskiej. U Juniewicza przeciętny szlachcic spędzał czas na nieróbstwie, przede wszystkim - na grze w karty i pijaństwie od rana, łykając co chwila „dubel-anyżu z flaszeczki”"29. To próżniacze życie w ujęciu paulina dopełniane było przez bezbrzeżną pychę, choć satyryk podkreślał, że dla tego

\footnotetext{
${ }^{26}$ Zob. ibidem, 1731 s. $51 ; 1753$ s. 79.

27 Zob. ibidem, 1731 s. $49 ; 1753$ s. 78.

${ }^{28}$ Zob. M. Bogucka, Białogłowa w dawnej Rzeczypospolitej, op. cit., s. 47 i nast.; K. M. Juniewicz, Refleksyje..., 1731 s. 52.

${ }^{29}$ K. M. Juniewicz, Refleksyje..., 1753 s. 66.
} 
wysokiego mniemania o sobie („że pan wielmożny”) jedynym fundamentem był „półrolek mały” ${ }^{30}$. Choć pogrążony w nędzy, prowincjonalny szlachcic Juniewicza

$$
\begin{aligned}
& \text { Z pychą powagi } \\
& \text { Jak indyk nagi } \\
& \text { Burcząc, zażywa [1753, s. 77]. }
\end{aligned}
$$

Całe życie tego „wielkiego pana” toczyć się miało się pośród łatanej odzieży, baranich kożuszków, starej strzelby, podniszczonej szabli, szczurów ${ }^{31}$, słomianej pościeli i poduszek... z cieląt, mieszkających w tej samej izbie, oraz oparów alkoholu ${ }^{32}$. Ten ostatni problem jest jednym $z$ ważniejszych składników satyrycznego rozrachunku z rzeczywistością ${ }^{33}$. Pijaństwu Juniewicz poświęcił około czterystu wierszy poematu — i choć temat podjął w połowie XVII wieku Krzysztof Opaliński, a satyra epoki chętnie do niego nawiązywała, to trzeba przyznać, że podejście paulina do tego problemu była diametralnie inne: Opaliński buduje wizję ogólną, z rzadka ją konkretyzując; Juniewicz natomiast skupia się na szczególach. Karykaturalny pijany dworek szlachecki stanowił u niego swoistą alegorię całej Rzeczypospolitej, oglądanej z perspektywy prowincjonalnej. W ten sposób swoisty reportaż z życia rodziny szlacheckiej posłużył do wyciągnięcia ogólnych wniosków.

Pijaństwu nieodłącznie towarzyszy u Juniewicza rozrzutnośc ${ }^{34}$, jako temat satyry obyczajowej poświadczana także u Potockiego, Opalińskiego, a wcześniej w Satyrze na twarz Rzeczypospolitej Twardowskiego i jeszcze wcześniej u Reja, a po raz pierwszy w przemyślany sposób piętnowana przez Frycza Modrzewskiego. Novum znamionującym inne czasy jest fakt, że rozrzutność u Juniewicza skojarzona została z ubóstwem; to ostatnie nie było ku zadziwieniu pisarza dla niej hamulcem — wprost przeciwnie, napędzało ją.

W związku z przemianami w kulturze pierwszej połowy XVIII wieku Juniewicz siłą rzeczy eksploatowal także tematy nowe, na tle zwyczajów, które przyszły do Polski z dworu drezdeńskiego - były to bale maskowe oraz swoboda obyczajowa ${ }^{35}$. Budziły one w autorze głęboką niechęć, odczuwał je jako zagrożenie dla świata tradycyjnych wartości sarmackiego społeczeństwa; dotyczyło to szczególnie posiadania metres i kochanków, co starał się spopularyzować „Saxe galant”, August II. Tą nową modę piętnuje paulin ostro, pisząc:

Tać to francuska,

Nie owa ruska

Trwa teraz moda,

${ }^{30}$ Ibidem, 1731 s. $46 ; 1753$ s. 38.

31 Zob. ibidem, 1731, s. 46; 1753, s. 38.

${ }^{32}$ Zob. ibidem, 1753, s. 76.

${ }^{33}$ Zob. ibidem, 1753, s. 42-47.

${ }^{34}$ Zob. ibidem, 1753, s. 57.

${ }^{35}$ Zob. J. Staszewski, Polacy w osiemnastowiecznym Dreźnie, Wrocław 1986, s. 95. 


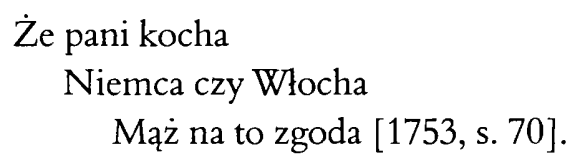

U Juniewicza te drezdeńsko-warszawskie zwyczaje są parodią samych siebie, bo są praktykowane wśród średniej szlachty w otoczeniu sygnalizowanej już wcześniej nędzy, co czyniło je tym bardziej groteskowymi. Skoro jednak odrzucimy prześmiewczy ton, to opisy codzienności w domu szlacheckim okażą się u Juniewicza zbieżne $z$ relacją Kitowicza. O ile jednak ten ostatni idealizował czasy saskie ${ }^{36}$, to Juniewicz daje ich drapieżny „obraz z natury”.

Obśmiawszy pychę szlachecką i zepsucie obyczajowe, nie pozostawił też Juniewicz suchej nitki na samej istocie szlachectwa ${ }^{37}$ - etosie rycerskim. Szlachta owszem, broni się świetnie - według słów paulina - ale nogami, uciekając z pola bitwy, a ponieważ krew szlachecka jest droga, więc szlachta jej skąpi ${ }^{38}$. Z ironią pisze więc:

\title{
Droga szlachecka \\ Krew, lecz niemiecka \\ W swym kusym stroju,
}

Ceny nie zważa [1753, s. 90].

Wypowiedź ta była niewątpliwie wyrazem przekonania o zbankrutowaniu ideałów rycerskich. Satyryk dostrzegł jednak z kolącą drwiną, że nie był to upadek całkowity. Polacy bowiem, kiedy

\author{
Zgrzeją się trunkiem, \\ Wraz się całują, \\ Wraz i wojują \\ Różnym rynsztunkiem, \\ To pistoletem, \\ To deski bretem, \\ To szkła pociskiem, \\ I kuflów czasem [1753, s. 95]. \\ 36 Zob. J. Kitowicz, Opis obyczajów za panowania Augusta III, opr. M. Dernałowicz, Warszawa 1999, \\ ${ }^{37}$ Tak jak je postrzegano w XVIII wieku. W XVI stuleciu pojęcie szlachectwa utożsamiano z cnotą.
} s. 241.

${ }^{38}$ Zob. K. M. Juniewicz, Refleksyje..., 1753 s. 77. 
Rzeczpospolita w tym krzywym zwierciadle ukazana została jako kraj bezprawia. Pisarz wyciąga na światło dzienne głęboko patologiczny charakter życia społecznego w Polsce,

\section{$[\ldots]$ gdzie zgrabić}

Wolno i zabić

Człeka jak sowę,

Gdy się nawinie

We złej godzinie [1753, s. 92].

Jak tłumaczy czytelnikowi paulin, dzieje się tak, bo

[...] w Polszcze wszytko

Wolno, co brzydko

Świat cały łaje [1753, s. 92].

Jedynym środkiem dla odnalezienia sprawiedliwości było oczywiście przekupstwo, jedna z tych patologii w Polsce schyłku czasów saskich, które powodować miały wedle Juniewicza „strach od Boga”, i które wprost „pomsty wołają”; w tym utyskiwaniu był on kontynuatorem tradycji, ale wtórował te ż Jabłonowskiemu $\mathrm{i}$ innym.

W mrocznej wizji Juniewicza w połowie wieku XVIII szlachta jest zdegenerowana, chlopi zepsuci, kobiety występne, a pijana Rzeczpospolita gnije. Tę ponurą diagnozę wykolejonego polskiego społeczeństwa zamyka poruszający radykalizmem obraz „tańca stanów", który swego czasu ujął Czesława Hernasa:

Jest to przysłowie

$\mathrm{W}$ podolskiej mowie,

Co się tu przyda:

Drze koza łozę,

Wilk zaś drze kozę,

A chłop dla Żyda

Z wilka drze skórę,

I wnet na lurę

Do karczmy wlecze,

Gdzie Żydek chłopka

Jak wróbel z snopka

Kłosy osiecze: 


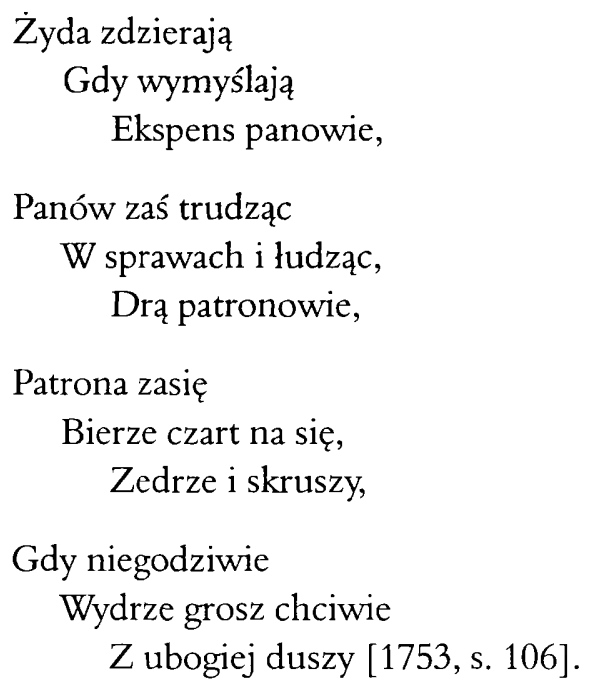

Autor wyklada pokrótce naczelne zasady w życiu społecznym Rzeczypospolitej: wyzysk, ucisk i przemoc. Manifestują się one nie tylko w życiu politycznym, ale i w codziennej egzystencji, w której do rozrywek należy bicie „dworskim korbaczem", a słabszych przywoluje się do porządku pięścią. Osobliwość polega na tym, że Juniewicz — sam szlachcic, a także duchowny — uderza w tony charakterystyczne raczej dla literatury kręgu plebejskiego. Jednak poprzez swój zakonny status wyłączony przynajmniej w pewnej mierze z życia świeckich, mógł Juniewicz dostarczyć jednego $z$ najostrzejszych w pierwszej połowie wieku XVIII obrazów życia codziennego w Rzeczypospolitej. Z tej perspektywy stworzył syntetyczną „satyrę na wszystko”, o spektrum niemal tak szerokim jak wspomniana na wstępie Matpa-cztowiek.

Wizja świata, rządzonego wyłącznie przez odwieczne prawo silniejszego, zbliża Juniewicza do tonacji literatury sowizdrzalskiej, o korzeniach antystanowych ${ }^{39}$. Ów związek był zresztą podkreślany przez Czesława Hernasa ${ }^{40}$. Do literatury plebejskiej odsyłają czytelnika również zasadnicze prawa rządzące światem przedstawionym w poemacie Juniewicza. Są nimi brutalna przemoc, fizyczne udręczenie, pragnienie ucieczki, wreszcie zasada siły przed prawem, która awansuje do roli ostoi „porządku” społecznego Rzeczypospolitej.

Satyra Juniewicza jest przesycona goryczą. Tym dobitniejszy efekt, że treści wyrażone są w potoczystym, pięciozgłoskowym, skocznym wierszu.

W tym Juniewiczowskim obrazie świata - błazeńskiego zwierciadła, wykrzywionym i zdeformowanym nie ma nic przypadkowego. Poeta bowiem był świadomym satyrykiem, co wyrazil, pisząc: 
Cyt! Pani Muzo [...]

Nie tykaj głosem,

Lecz uchodź z nosem

Od Pańskiej bramy,

Nieraz ten miewa,

Co szczerze śpiewa,

W nagrodę plagi [1753, s. 49].

I w tym także ten doktor teologii, witający niegdyś wyrafinowaną lacińską mową wjeżdżającego do Polski Augusta III, jest po części spadkobiercą literatury plebejskiej: ostatnią instancją, która zamyka usta krytyka, jest kij. 